\title{
PENGARUH TELEVISI (TV) TERHADAP ASPEK-ASPEK PERKEMBANGAN ANAK USIA 3-4 TAHUN
}

\author{
Gifari Annisa Rohani \\ Fakultas Ilmu Pendidikan, Universitas Negeri Yogyakarta \\ email: gifariannisa@gmail.com \\ PAUD Universitas Negeri Yogyakarta
}

\begin{abstract}
Abstrak
Salah satu media yang dekat dengan anak-anak baik di sekolahan maupun di sekolah yakni televisi. Televisi termasuk ke dalam media audio-visual. Kebanyakan orang tua mempercayai bahwa televisi membawa dampak buruk bagi anak. Akan tetapi hal tersebut tidaklah benar. Televisi sebagai sebuah media pembelajaran juga membawa dampak positif bagi anak. Dampak positif tersebut yakni meningkatkan aspek tumbuh kembang anak usia dini yang mencakup nilai kognitif, bahasa, emosi sosial, motorik, moral dan agama. Penelitian ini bertujuan untuk menemukan dampak dari media pembelajaran berupa televisi pada aspek tumbuh kembang anak usia dini. Penelitian ini termasuk penelitian kualitatif yang menggunakan sebuah model interaktif milik Miles dan Huberman. Hasil penelitian menunjukkan bahwa televisi memberikan dampak positif dan negatif bagi anak-anak. Dampak positif tersebut berupa peningkatan semua aspek perkembangan anak usia dini sehingga anak menjadi lebih komunikatif, imaginatif, dan aktif. Sedangkan dampak negatifnya berupa penurunan prestasi belajar anak yang akibat terlalu sering menonton televisi.
\end{abstract}

Kata kunci: televisi sebagai media pembelajaran, dampak televisi, televisi untuk pendidikan anak usia dini

\begin{abstract}
One medium that is close to the children, either at home or at school is a television. Television included in the audio-visual media. Most parents believe that television brings negative effects for children. But this is not true. Television as a learning media also has a positive effect for children. The positive effect by increasing aspects of early childhood development, which includes cognitive, language, social emotional, motoric, moral and religious values. The aim of this study was to determine the effect of learning media in the form of television on aspects of early childhood development. This study is a qualitative study using an interactive model by Miles and Huberman. From this study showed that television gives a positive and negative effect to children. The positive effect by increasing all aspects of early childhood development as children become communicative, imaginative, and active. The negative effect in the form of a decline in learning achievement of children because too often watch television..
\end{abstract}

Keywords: television as a learning media, effect of television, television for early childhood education.

\section{PENDAHULUAN}

Pendidikan merupakan modal dasar untuk menyiapkan insan yang berkualitas. Dalam proses pendidikan, guru tidak terlepas dari media dan teknologi. Guru dan buku teks tidak lagi menjadi sumber seluruh informasi
(Sharon E. Smaldino, Deborah L. Lowther, James D. Russell, 2011: 4). Guru telah menjadi fasilitator pemerolehan informasi. Guru kini bukanlah sumber informasi tunggal. Informasi bisa didapat dari berbagai sumber, salah satunya adalah dengan pemanfaatan teknologi. 
Belakangan ini ketika sebagian besar orang-orang mendengar kata teknologi, mereka memikirkan benda-benda seperti komputer, pemutar MP3, televisi, HP, dan masih banyak lainnya. Kata teknologi selalu memiliki berbagai penafsiran, mulai dari sekadar perangkat keras hingga cara yang sitematis dalam menyelesaikan masalah. Di era modern ini berbagai macam teknologi dimanfaatkan di dalam kelas, tidak hanya sebatas pada penggunaan tape recorder untuk senam.

Perlu diketahui bahwa perangkat teknologi masuk dalam ketegori media pembelajaran. Media pembelajaran merupakan unsur yang sangat penting dalam upaya mencapai tujuan secara optimal. Media merupakan salah satu alat penyampai materi kepada siswa. Menurut Muhammad Fadlillah (2014: 211), ada 3 jenis media pembelajaran, yaitu media audio, media visual, dan media audiovisual. Perangkat teknologi seperti yang telah disebutkan sebelumnya masuk dalam media eletronik. Media elektronik bisa masuk dalam ketiga media pembelajaran tersebut.

Media pembelajaran sebaiknya bisa dimainkan oleh anak-anak sendiri. Sehingga saat tidak ada guru, anak-anak mampu melakukan trial and eror sebagai salah satu upaya agar anak-anak mampu memecahkan masalahnya sendiri. Menurut Oemar Hamalik (Cecep Kustandi \& Bambang Sutjipto, 2013: 19) bahwa pemakaian media pembelajaran dalam proses belajar mengajar dapat membangkitkan keinginan dan minat baru, membangkitkan motivasi dan rangsangan kegiatan belajar, dan bahkan membawa pengaruh-pengaruh psikologis terhadap siswa.

Penggunaan media mempunyai tujuan memberikan motivasi kepada siswa. Selain itu media juga harus merangsang anak untuk mengingat apa yang sudah dipelajari selain memberikan rangsangan belajar baru. Media yang baik juga harus mengaktifkan anak dalam memberikan rangsangan, umpan balik, dan juga mendorong siswa untuk melakukan parktik-praktik dengan benar.

Ada berbagai perangkat teknologi atau media elektronik yang ada di sekitar anak-anak. Salah satu media yang paling banyak digunakan anak-anak, baik di rumah maupun di sekolah adalah televisi (TV). TV merupakan salah satu media elektronik yang dengan mudah lekat dengan anak-anak. Selain itu, TV merupakan media eletronik yang mudah diadaptasi dalam penggunaannya oleh anak-anak. TV masuk dalam kategori media audio visual dengan jenis audiovisual bergerak. Menurut Muhammad Fadlillah (2014: 211) yang dimaksud dengan media audiovisual adalah media yang mempunyai unsur suara dan unsur gambar. Jenis media ini dibedakan menjadi dua, yaitu audiovisual diam dan audiovisual bergerak.

$\begin{array}{ccc}\text { Media yang baik sebaiknya mampu } \\ \text { mengembangkan } & \text { berbagai aspek }\end{array}$
perkembangan anak usia dini. Aspek-aspek perkembangan anak usia dini meliputi aspek perkembangan bahasa, kognitif, social emosional, motoric, dan Nilai Agama Moral (NAM). Apabila TV sebagai media elektronik mampu berperan dalam mengoptimalkan aspek-aspek perkembangan anak usia dini, maka TV layak untuk menjadi media pembelajaran bagi anak usia dini.

Dari paparan di atas dapat diketahui bahwa media elektronik mempunyai peranan penting dalam proses pembelajaran. Namun fakta yang di lapangan menunjukkan bahwa sebagian besar orang tua menganggap bahwa TV sebagai media elektronik selalu membawa dampak negatif bagi anak-anak mereka. Selain itu, orang tua dan sebagian besar pendidik belum mengetahui lebih dalam pengaruh TV terhadap aspek-aspek perkembangan anak usia dini.

\section{TELEVISI}

Teknologi memainkan peran penting dalam pendidikan. Teknologi yang disesuaikan dan dirancang secara sedemikian rupa mampu memberi kontribusi bagi pengajaran yang efektif dari seluruh anak didik dan bisa membantu anak didik untuk meraih potensi tertinggi mereka, terlepas dari kemampuan bawaan anak.

Kata teknologi berasal dari bahasa
Yunani technologia. Techne artinya
kemampuan dan logia berarti ungkapan.
Teknologi merupakan istilah yang luas
berkaita dengan pemanfaatan dan
pengetahuan tentang perkakas dan
ketrampilan (Wikipedia dalam Sharon E.
Smaldino, Deborah L. Lowther, James D.


Russell, 2011: 4). Seperti yang telah dijelaskaan sebelumnya bahwa teknologi sering disebut dengan media eletronik dan masuk dalam media pembelajaran. Teknologi disini diartikan sebagai teknologi pengajaran.

Teknologi pengajaran merupakan pemanfaatan dan pengetahuan spesifik dari perkakas dan ketrampilan dalam pendidikan. Maksudnya adalah teknologi dimanfaatkan dalam pengajaran sehingga teknologi memiliki peranan untuk membantu pembelajaran menjadi lebih efektif dan efisien. Menurut Sharon E. Smaldino, Deborah L. Lowther, James D. Russell (2011: 14), teknologi dan media mempunyai banyak peranan. Jika pengajarannya berpusat pada guru, teknologi dan media digunakan untuk mendukung penyajian pengajaran. Di sisi lain, apabila pengajaran berpusat pada siswa, para siswa merupakan pengguna utama teknologi dan media.

Pengertian ini didukung oleh Darwanto (2007: 101) yang menyatakan bahwa penggunaan alat audio visual seperti alat teknologi, ditujukan untuk meningkatkan efektivitas dan efisiensi proses belajar mengajar, sehingga diharapkan anak-anak mampu mengembangkan daya nalar serta daya rekanya. Hasil berbagai penelitian menunjukkan bahwa proses belajar dan mengajar dengan menggunakan sarana audio visual mampu meningkatkan efisiensi pembelajaran $20 \%-50 \%$.

George S. Morrison (2012: 52), menyatakan bahwa penggunaan teknologi dalam program pendidikan anak usia dini itu perlu. Alasan George S. Morrison mengenai pentingnya pentingnya teknologi bagi pendidikan anak usia dini yang pertama adalah anak-anak sekarang adalah generasi teknologi. Anak-anakk banyak menggunakan teknologi dan telah bertahun-tahun bermain dan belajar dari teknologi. Program-program tertentu khusus dirancang untuk anak-anak dan program tersebut mudah digunakan dan menyenangkan, dan anak-anak dapat belajar darinya. Alasan yang kedua adalah penggunaan teknologi dalam program pendidikan anak usia dini dapat mulai menyamaratakan wilayah permainan edukatif dan menghilangkan perbedaan kepemilikan alat teknologi yang muncul di antara anak kaya dan anak miskin.
Salah satu perangkat teknologi yang paling dekat dengan anak-anak, saat ini adalah televisi (TV). Semula dinilai bahwa TV kurang bermanfaat dalam dunia pendidikan, hal ini mengingat biaya operasionalnya yang cukup mahal, tetapi kemudian muncul pendapat-pendapat yang berlawanan, yang menyatakan bahwa TV sebagai media massa sangat bermanfaat dalam memajukan pendidikan suatu bangsa (Darwanto, 2007: 117). Dari pendapat tersebut dalam perkembangannya membuktikan bahwa dengan sifat audio visual yang dimiliki TV, menjadikan TV sangat pragmatis, sehingga mudah mempengaruhi penonton dalam hal sikap, tingkah laku, dan pola pikirnya.

Dalam hal efektivitasnya dalam menjalankan fungsinya, di depan rapat staf Menteri Penerangan Republik Indonesia, DR. Jack Lyle (Darwanto, 2007: 118), Director of Communication Institute The West Center, menyatakan yang diterjemahkan dalam bahasa Indonesia, bahwa televisi untuk kita sebagai "jendela dunia", apa yang kita lihat melalui jendela ini, sangat membantu dalam mengembangkan daya kreasi kita, hal ini seperti diungkapkan oleh Walter Lippman beberapa tahun yang lalu, bahwa dalam pikiran kita ada semacam ilustrasi gambar dan gambar-gambar ini merupakan suatu yang penting dalam hubungannya dengan proses belajar, terutama sekali yang berkenaan dengan orang, tempat, dan situasi yang tidak setiap orang pernah ketemu, mengunjungi atau telah mempunyai pengalaman.

Dari penjelasan Lyle di atas jelas sekali bahwa TV mampu memberikan apresiasi kepada khalayak penonton. Saat seseorang melihat susunan gambar di layar $\mathrm{TV}$, maka orang tersebut akan merasakan sesuatu yang baru, disebabkan penonton tadi hampir tidak dapat membedakan mana yang pernah dilihat, atau dengan kata lain penonton tadi hampir tidak dapat membedakan pengalaman yang telah dimiliki. Hal ini berarti bahwa audio visual dapat memberikan pengalaman-pengalaman yang baru sesuai dengan pengalaman yang telah dimiliki sebelumnya, atau dapat memberikan "pengalaman semu" atau "stimulated experience" (Darwanto, 2007: 118-119). 
Berikut ini adalah gambaran dari penjelasan di atas, yakni:

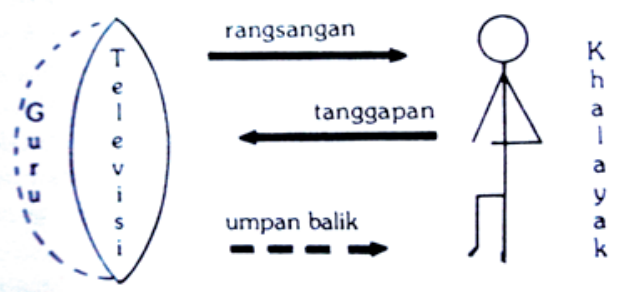

Gambar 1. Pengaruh TV terhadap penonton (Darwanto, 2007: 119)

Stimulated experience ini misalnya:

1. Melihat sesuatu yang belum pernah dilihat sebelumnya

2. Berjumpa dengan sesorang yang sebelumnya belum pernah dijumpai

3. Datang ke suatu tempat yang belum pernah dijumpai

Perihal penggunaan TV, khususnya di sekolah, memang besar sekali manfaatnya, seperti diungkapkan oleh Oemar Hamalik (Darwanto, 2007: 124) sebagai berikut:

1. TV bersifat langsung dan nyata

2. TV memperluas tinjauan kelas

3. TV dapat menciptakan kembali semua peristiwa yang lalu

4. TV dapat menunjukkan banyak hal dan segi

5. TV menarik minat, bukan saja anak-anak tetapi juga orang dewasa

6. TV mampu memberi bantuan kepada guru

7. TV mampu membawa sumber-sumber yang ada di masyarakat ke dalam kelas

8. Masyarakat akhirnya mengerti tentang sekolah secara nyata.

Membimbing anak dalam menonton TV tidaklah semudah yang dikatakan. Hal ini dikarenakan TV memiliki sifat-sifat seperti yang telah disebutkan di atas. Televisi (TV) adalah media yang cepat menyebar di masyarakat. Melalui teknologi seperti TV dapat membantu anak untuk mengembangkan hubungan pertemanan yang positif, menumbuhkan kemampuan mereka dalam pengaturan dan pengendalian diri, dan mengembanngkan kepercayaan diri yang positif. Saat penggunaan TV, maka interaksi antara guru dan anak-anak akan mudah terjalin. Interaksi dan hubungan anak dengan orang lain memperluas pandangan mereka tentang dunia dan diri mereka sendiri. Usia dini juga merupakan waktu dimana anak belajar tentang pengendalian diri dan kemandirian. Orang dewasa mengharapkan anak untuk membuat peraturan diri, mengendalikan diri, dan beraktivitas tanpa diawasi terus menerus. Cara anak memenuhi harapan-harapan ini berdampak besar terhadap perkembangan social mereka (George S. Morrison, 2012: 116).

Franklin (Darwanto, 2007: 126) berpendapat bahwa melalui media TV, dapat membantu di dalam memecahkan masalahmasalah pendidikan, apalagi kita dapat memanfaatkan penggunaan berbagai alat audio visual, dimana media massa lain tidak memungkinkan. Hal ini berarti bahwa pendapat Franklin mendukung pendapat dari George S. Morrison mengenai penggunaan TV terhadap anak usia dini.

Dari kedua pendapat di atas dapat disimpulkan bahwa TV mampu meningkatkan kemampuan belajar, bukan saja untuk anakanak memlainkan juga untuk semua tingkatan usia. Harus diingatkan kembali bahwa TV bagaimanapun hanya merupakan "alat". Karena itu berhasil tidaknya penggunaan TV sebagai alat bantu dalam proses belajar mengajar tergantung dari baik buruknya program siaran yang dibuat dan bagaimana cara orang tua dan guru untuk memilih siaran yang tepat untuk anak-anak mereka.

Siaran TV bagaimanapun tetap menarik bagi anak-anak dan dapat membantu anak-anak belajar yang lebih baik. Sebab TV mampu menyajikan bahan yang bergerak dinamis, sehingga merangsang perhatian anak-anak. Dengan demikian anak-anak lebih tertarik dan mencernakannya.

\section{ASPEK PERKEMBANGAN ANAK USIA 34 TAHUN}

Perlu diingat bahwa masa usia dini merupakan masa keemasan (golden age). Masa keemasan (golden age) menurut Miftahul Achyar Kertamuda (2015: 2) ialah masa anak usia dini untuk mengeksplorasi hal-hal yang ingin mereka lakukan, masa golden age merupakan masa penting untuk membentuk karakter anak. Selain itu, anak usia dini sangat mudah menangkap informasi dari berbagai sumber. Oleh karena itu, usia dini merupakan kesempatan yang sangat berharga yang tidak boleh terabaikan. 
Sehubungan dengan hal tersebut, dalam mendidik anak usia dini perlu dilakukan dengan tepat.

Mendidik anak adalah tanggung jawab utama bagi orang tua di rumah dan guru saat di sekolah. Orang tua dan guru perlu memberikan banyak stimulasi yang konkret pada anak agar anak benar-benar memahami apa yang selama ini orang tua dan guru berikan kepada diri mereka.

Masa keemasan (golden age) seorang anak adalah merupakan masa paling penting bagi pembentukan pengetahuan dan perilaku anak. Pada masa keemasan pertumbuhan otak anak sedang mengalami perkembangan yang sangat pesat (eksplosif). Miftahul Achyar Kertamuda (2015: 4) menyatakan bahwa anak usia 0-4 tahun, perkembangan kecerdasannya mencapai $50 \%$. Oleh sebab itu, banyak para orang tua yang kemudian memberikan berbagai macam stimulasi sejak anak berusia dini.

Stimulasi yang diberikan oleh orang tua mempunyai tujuan agar anak-anak mereka mampu tumbuh dan berkembang dengan baik sesuai dengan tahap-tahap perkembangan anak. Masa kanak-kanak memiliki tempat yang istimewa di dalam rangkaian hidup manusia. Karena di masa kanak-kanak inilah manusia belajar banyak hal dan akan dijadikan sebagai landasan untuk pembelajaran yang selanjutnya. Untuk dapat belajar banyak hal, manusia pun harus melewati masa-masa pertumbuhan dan perkembangan.

Stimulasi yang diberikan oleh orang tua di rumah dan guru di sekolah bisa berupa penggunaan teknologi yang dekat dengan anak-anak, yaitu TV. TV tidak selalu berdampak negative terhadap aspek-aspek perkembangan anak, namun juga bisa berdampak positif. Semua itu tergantung dari guru dan orang tua saat melakukan proses pemilihan teknologi itu sendiri.

\section{METODE PENELITIAN}

Sejalan dengan focus masalah dan tujuan penelitian, maka peneliti menggunakan jenis penelitian kualitatif. Denzin dan Lincoln (Nusa Putra, 2012: 66) menguraikan bahwa penelitian kualitatif merupakan focus perhatian dengan beragam metode, yang mencakup pendekatan interpretative dan naturalistic terhadap subjek kajiannya. Penelitian kualitatif mencakup subjek yang dikaji dan kumpulan berbagai data empirisstudi kasus, pengalaman pribadi, introspeksi, perjalanan hidup, wawancara, teks-teks hasil pengamatan, historis, interaksional, dan visual yang menggambarkan saat-saat dan makna keseharian dan problematis dalam kehidupan seseorang.

Penelitian kualitatif bertujuan untuk memahami subjek penelitian secara mendalam dan bersifat interpretative, artinya mencari temuan makna. Menurut Jane Richie (Moleong, 2007: 6), mengungkapkan bahwa penelitian kualitatif adalah upaya untuk menyajikan dunia social dan perspektifnya di dalam dunia, dari segi konsep, perilaku, persepsi, dan persoalan tentang manusia yang diteliti.

Sejalan dengan pengertian di atas, Subjek penelitian pada kegiatan penelitian ini adalah anak-anak Kelompok Bermain yang berusia 3-4 tahun di PAUD An Nuur. Kemudian objek penelitiannya adalah aspekaspek perkembangan dari anak usia 3-4 tahun di PAUD An Nuur. Kemudian, kegiatan penelitian ini dilakukan di PAUD An Nuur, khususnya untuk Kelompok Bermain. PAUD An Nuur beralamatkan di Jl. Magelang Km. 12, Yogyakarta.

Dalam membahas tentang analisis data dalam penelitian kualitatif, terdapat banyak model dari para ahli. Dalam penelitian ini menggunakan model interaktif Miles dan Huberman. Tahap-tahap dari model interaktif ini terlihat dalam gambar berikut ini:

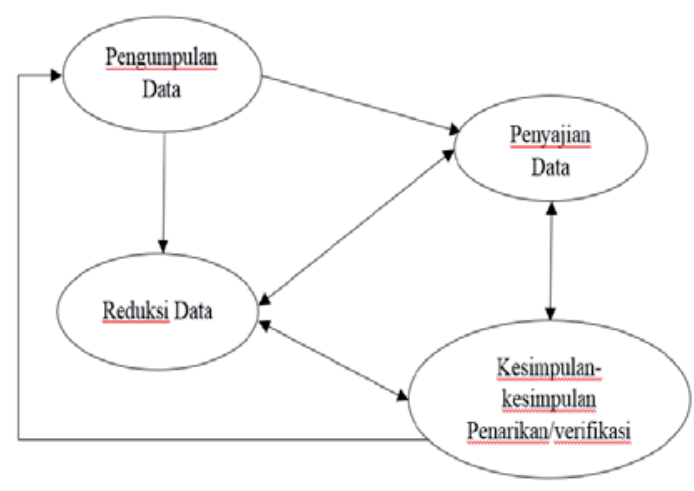

Gambar 2. Komponen-komponen Analisis Data Model Interaktif Miles dan Huberman (2014: 20) 
Dari gambar di atas, maka dapat diketahui bahwa ada 4 tahap dalam analisis data kualitatif dengan model interaktif Miles dan Hueberman, yaitu pengumpulan data, reduksi data (penyederhanaan data), penyajian data, dan penarikan kesimpulan.

Teknik pengumpulan data yang utama dalam penelitian ini adalah observasi, angket, dan wawancara. Teknik observasi bertujuan untuk mengetahui pelaksanaan pembelajaran dengan menggunakan TV di PAUD An Nuur. Peneliti melaksanakan pengamatan dengan menggunakan pedoman observasi untuk memperoleh data yang diinginkan dan setiap informasi yang ditemukan dicatat. Kemudian teknik yang kedua adalah angket. Angket merupakan daftar pertanyaan yang diberikan kepada walimurid dan orang tua untuk mengetahui pengaruh TV selama di rumah. Angket yang digunakan dalam penelitian ini berupa angket campuran. Dan teknik yang terakhir adalah wawancara. Wawancara dilakukan oleh peneliti dengan cara berbincang-bincang dan memberikan sejumlah pertanyaan kepada guru untuk menggali lebih lanjut bagaimana pengaruh TV terhadap aspek-aspek perkembangan anak.

\section{HASIL DAN PEMBAHASAN}

Berdasarkan penelitian yang telah dilakukan selama 2 hari, di dapatkan hasil bahwa TV memang memiliki dampak terhadap aspek-aspek perkembangan anak usia dini, khususnya anak usia 3-4 tahun. Dampak dari TV tidak semuanya berdampak negatif. TV juga memberikan dampak positif terhadap anak-anak.

Saat observasi, terlihat sekali bahwa anak-anak antusias dan senang. TV yang ada di sekolah, pada saat pembelajaran dimanfaatkan untuk memutar video, lagu, film, siaran di TV yang bersifat edukatif. Anak-anak selalu meminta kepada guru untuk memutar ulang apa yang baru saja mereka tonton dan berusaha mengikuti apa yang mereka tonton. Saat mereka mulai hafal, mereka akan mulai untuk mengikuti. Setelah anak-anak hafal, mereka meminta untuk ganti saluran atau tayangan yang lain. Respon anak-anak sangat baik dan menerima adanya penggunaan TV dengan senang hati. Bahkan terkadang anak-anak melebihi batas waktu saat menonton TV di sekolah karena anak- anak sangat antusias. Waktu yang diberikan kepada anak-anak untuk menonton TV adalah sekitar 15 menit. Apabila tidak ada pembelajaran lainnya, guru memperbolehkan anak-anak untuk menonton TV lagi sampai 20 atau 30 menit. Batas waktu maksimal yang diberikan guru adalah 30 menit dalam sehari untuk menonton TV.

Setelah melihat respon anak-anak yang cukup baik, selanjutnya peneliti melakukan wawancara dengan guru KB. Berdasarkan hasil wawancara didapatkan hasil bahwa TV yang digunakan di sekolah memang mempunyai pengaruh positif terhadap anak-anak usia 3-4 tahun di seluruh aspek perkembangan anak usia dini.

Dari aspek perkembangan bahasa, anak-anak menjadi lebih komunikatif. Anakanak menjadi lebih berani mengungkapkan gagasan-gagasan mereka. Bagi anak-anak yang belum lancar dalam berbicara, TV menjadi stimulasi yang tepat bagi anak-anak. Saat dipertontonkan tayangan yang tepat dan sesuai dengan anak-anak, anak-anak mau mengikuti apa yang ada di TV. Saat ada lagu anak menjadi mulai berguman, lalu saat anak mulai hafal, anak akan mulai ikut bernyanyi. Saat mereka hafal, mereka akan menyanyi dnegan suara yang lantang.

Selain itu, anak-anak mampu untuk menceritakan kembali kepada orang lain mengenai apa yang telah mereka tonton. Baik kepada guru, teman sebaya, atau bahkan orang tua mereka saat anak-anak dijemput. Anak menjadi lebih aktif lagi apabila apa yang dipertontonkan kepada mereka merupakan tayangan favorit mereka.

Dari aspek motoric, anak aktif untuk bergerak. Hal ini biasanya berhubungan dengan video atau tayangan gerak dan lagu. Saat mendengar lagu, anak-anak akan bergerak walapun hanya goyang ke kanan dan kiri. Apabila tayangan berhubungan dengan gerakan-gerakan yang lucu dan menarik, anak-anak akan berusaha mengikuti.

Dari aspek social emosional, anak menjadi lebih mudah berinteraksi, karena tayangan yang mereka tonton biasanya berupa percakapan atau pertanyaan yang mendorong anak-anak untuk terus berinteraksi. Anak menjadi berani, berani mengungkapkan berpendapat, berani maju ke depan (tidak 
malu-malu lagi). Selain itu anak-anak dituntut untuk saling berbagi tempat duduk untuk bisa menonton TV bersama. Karena biasanya anak-anak akan maju ke depan semua saat menonton TV. Namun guru membuat kesepatan bersama anak. Apabila ada teman yang melanggar, maka teman yang lainnya akan memperingatkan. Dari kegiatan tersebut anak belajar berbagi dan bersabar agar tidak mudah marah dengan teman sendiri.

Dari aspek kognitif, anak menjadi lebih aktif berfikir. Saat anak menonton tayang TV, terkadang guru menghentikan tayangan untuk sementara dan bertanya kepada anak-anak mengenai apa yang akan terjadi, apa nama dari benda yang ditunjuk guru, bagaimana ciri benda tersebut, dan pertanyaan-pertanyaan lainnya yang mengarahkan anak untuk berfikir kreatif. Selain itu, tayangan yang di TV membuat anak menjadi imajinatif. Biasanya anak meniru tokoh idola yang ada di TV.

Dari aspek NAM, anak-anak menjadi lebih mudah mengucapkan sesuatu dalam bahasa Arab. Misalnya menyebutkan Asmaul Husna, hafal doa-doa atau surat-surat pendek. Anak menjadi lebih mudah untuk menghafal dan mengingat. Berikut ini adalah foto saat pembelajaran menggunakan TV, yakni:

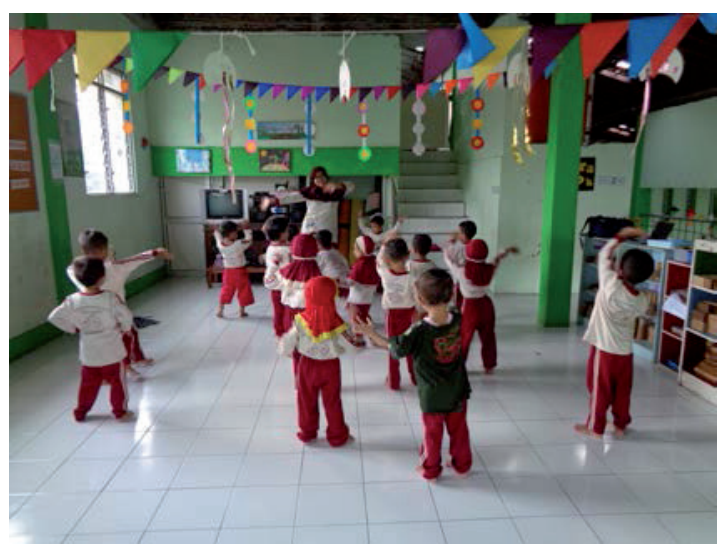

Foto 1. Anak mengikuti gerakan yang ada di TV

Pada saat observasi, ada 18 anak yang ikut serta dalam pembelajaran menggunakan TV. Namun pada penyebaran angket, hanya 13 angket yang kembali dari 18 angket yang diberikan kepada orang tua atau walimurid.

Berdasarkan hasil angket yang kembali yaitu 13 angket, dapat diketahui bahwa hampir seluruh anak KB di PAUD An
Nuur terpengaruh oleh tayangan di TV. Pengaruh tersebut berupa:

- Anak meniru apa yang mereka tonton. Padahal anak-anak belum paham apa yang mereka ikuti

- Anak menjadi nafsu makan supaya kuat

- Anak hafal dengan adegan yang ada di TV

- Anak hafal jam tayang dan selalu ingin menonton lagi

- Imajinasi anak menjadi bagus, hal ini terlihat saat bermain peran

- Anak mampu bercerita kembali mengenai apa yang sudah mereka tonton

- Anak suka meniru kata-kata tokoh idola mereka

- Meniru gaya dari tokoh idola

Selain yang telah disebutkan di atas, TV juga memiliki dampak negative yaitu membuat anak malas untuk belajar. $60 \%$ anak menjadi malas belajar apabila sudah di depan TV. Rata-rata anak menonton TV tidak lebih dari 2 jam/hari selama di rumah sehingga dampak negative yang muncul sebatas pada prestasi belajar yang menurun. Selama menonton $\mathrm{TV}$, anak-anak juga jarang untuk makan dan minum yang berlebihan sehingga resiko obesitas terhadap anak-anak dapat disimpulkan bisa dihindari.

Dari angket, orang tua atau walimurid juga menyatakan bahwa upaya yang dilakukan orang tua untuk mencegah waktu layar anak di depan TV adalah dengan mengajak anak-anak bermain atau melakukan kegiatan yang disukai anak. Misalnya bermain lego, bermain mobil-mobilan, mewarnai, menggambar. Para orang tua atau walimurid juga menyadari bahwa waktu layar anak di depan TV yang berlebihan akan menyebabkan dampak negative lainnya selain anak malas belajar, sehingga orang tua atau walimurid berusaha untuk membatasi waktu layar anak.

Selain upaya untuk mencegah waktu layar anak di depan $\mathrm{TV}$, orang tua atau walimurid juga berupaya agar anak-anak tetap belajar setiap hari. Upaya-upaya tersebut antara lain:

- Orang tua membuat kesepakatan bersama anak, kapan waktu menonton TV dan kapan waktu belajar

- Menegur dan mengingatkan anak untuk tidak menonton TV terlalu lama 
- Mematikan TV

- Belajar sambil bermain

- Anak-anak dialihkan untuk menonton gambar binatang sehingga anak-anak lupa akan acara di TV

- Orang tua membatasi waktu layar anak di depan TV dalam sehari

- Apabila anak marah karena dilarang menonton TV yang terlalu lama, orang tua melepas antenna TV dan memasukkan TV ke kardus.

Uraian-uraian di atas merupakan hasil penelitian yang dilakukan selama 2 hari di PAUD An Nuur. Teknik yang digunakan dalam mengumpulkan data adalah dengan observasi, angket, dan wawancara.

\section{KESIMPULAN}

Berdasarkan dari hasil penelitian di atas, maka dapat disimpulkan bahwa TV mampu mengembangkan aspek-aspek perkembangan anak usia dini, khususnya usia 3-4 tahun. TV tidak selalu berdampak negative terhadap perkembangan anak usia dini. TV juga mempunyai dampak positif apabila digunakan secara bijak dan pemilihan tayangan yang baik dan bersifat edukatif.

Dari aspek bahasa, anak menjadi lebih komunikatif dan lancar dalam berbahasa. Dari aspek motoric, anak menjadi lebih aktif bergerak. Dari aspek social emosional, anak menjadi mudah dalam berinteraksi dengan orang lain. Anak mempunyai kepercayaan diri dan tidak takut atau malu untuk tampil di depan teman-teman yang lainnya. Dari aspek kognitif mampu mengembangkan daya imajinatif dan daya nalar anak. Dari aspek NAM, anak menjadi lebih mudah belajar menghafal dan mengingat doa-doa, surat-surat, nama benda dalam bahasa Arab, dan Asmaul Husna.

Setelah diteliti lebih jauh, dampak positif tidak hanya terjadi di sekolah, melainkan juga di rumah. Anak menjadi nafsu makan karena ingin kuat seperti tokoh idola mereka, anak menjadi lebih aktif untuk bercerita kembali mengenai apa yang sudah mereka tonton, imajinasi anak juga meningkat, daya ingat anak juga menjadi baik.

Selain dampak positif, penggunaan TV di rumah juga memiliki dampak negative.
Dampak negative tersebut adalah anak menjadi malas untuk belajar apabila sudah menonton TV. Namun, para orang tua atau walimurid tidak hanya diam saja. Orang tua atau walimurid membatasi waktu layar anak hanya selama $2 \mathrm{jam} /$ hari. Apabila anak sudah menonton TV terlalu lama, maka orang tua atau walimurid menegur dan mengingatkan anak-anak. Lalu mengalihkan perhatian mereka dengan menyuruh anak-anak untuk bermain atau melakukan kegiatan yang mereka sukai.

Selain itu, orang tua atau walimurid juga mengupayakan agar anak-anak tetap mau belajar. Orang tua atau walimurid menyadari bahwa TV tetap memiliki dampak negative dan anak-anak tetap harus belajar. Dampak yang berupa anak suka meniru tokoh idolanya, bisa termasuk dalam dampak positif dan negative. Tergantung kepada peniruan yang ditiru oleh anak itu sendiri. Apabila apa yang ditiru anak merupakan hal yang kurang baik, maka orang tua atau walimurid akan memperingatkan anak-anak mereka dan berusaha menjelaskan kepada mereka bahwa apa yang mereka tiru bukanlah hal yang baik.

Dari penelitian di atas dapat dieketahui bahwa TV tidak selalu berdampak buruk terhadap anak-anak. TV dapat memberikan dampak positif apabila orang tua dan guru lebih teliti dalam memberikan tontonan yang positif terhadap anak-anak. Tayangan yang diberikan kepada anak-anak sebaiknya bersifat edukatif sehingga dampak positif tidak hanya berkembang di sekolah tetapi juga di rumah.

Selan itu, dari hasil penelitian di atas juga disebutkan bagaimana cara atau upaya agar anak tetap mau belajar. Upaya-upaya tersebut merupakan hasil angket dari orang tua. Orang tua seyogyanya memang tetap mengupayakan anak untuk tetap belajar walaupun TV sebagai media juga merupakan alat atau media untuk menyampaikan pembelajaran. Upaya-upaya tersebut dapat menjadi acuan bagi orang tua dan guru dalam menggunakan TV sebagai media pembelajaran di sekolah dan juga di rumah. 


\section{DAFTAR PUSTAKA}

Arief S. Sadiman, dkk. (2009). Media Pendidikan: Pengertian, Pengembangan, dan Pemanfaatannya. Jakarta: Rajawali Pers

Azhar Aryad. (2015). Media Pembelajaran. Edisi revisi. Jakarta: Rajawali Pers

Cecep Kustandi \& Bambang Sutjipto. (2013). Media Pembelajaran. Bandung: PT Remaja Rosdakarya

Darwanto. (2007). Televisi sebagai Media Pendidikan. Yogyakarta: Pustaka Pelajar

Lexy J. Moleong. (2007). Metodologi Penelitian Kualitatif. Bandung: PT Reamaja Rosdakarya

Miles, Matthew B. \& Huberman, A. Michael. (2014). Analisis Data Kualitatif. (Alih bahasa: Tjetjep Rohendi Rohidi). Jakarta: UI-Press

Miftahul Achyar Kertamuda. (2015). Golden Age: Strategi Sukses Membentuk
Morrison, George S. (2012). Dasar-Dasar Pendidikan Anak Usia Dini (PAUD). (Alib bahasa: Suci Romadhon \& Apri Widiastuti). Jakarta: Indeks

Muhammad Fadlillah. (2014). Desain Pembelajaran PAUD. Yogyakarta: ArRuzz Media

Muhammad Idrus. (2009). Metode Penelitian Ilmu Sosial Pendekatan Kualitatif dan Kuantitatif. Jakarta: Erlangga

Nusa Putra dan Ninin Dwilestari. 2012. Penelitian Kualitatif PAUD: Pendidikan Anak Usia Dini. Jakarta: Rajawali Pers

Smaldino, Sharon E., Lowthter, Deborah L., Russel, James D. (2011). Instructional Technology and Media for Learning: Teknologi Pembelajaran dan Media untuk Belajar. (Alih bahasa: Arif Rahman). Jakarta: Kencana 